\title{
Corrosion Study of Glaze-Ceramics Doped Cement-Kiln-Dust Soaked in Concentrated HCI
}

\author{
F.A. Essa, T.D. Abd-Elaziz", M.R. Zakariya** and F.M. Ezz- \\ Eldin ${ }^{* * *}$ \\ Chem. Dept., Faculty of Sci. Menufya Univ., Menufya, *MSA \\ University (October Univ. for Modern Sciences and Arts), $6^{\text {th }}$ \\ October City, ${ }^{* *}$ Color Preparation Dept., Ceramica-Marselia \\ Factory and ${ }^{* * * *}$ National Center for Radiation Research and \\ Technology, Cairo, Egypt.
}

\begin{abstract}
WEW glaze-ceramics formulated from industrial waste have been prepared. The method consists of introducing cement-kiln-dust (CKD) in the industrial glaze-ceramics with various ratios $(10-50 \%)$ together with the addition of $10 \mathrm{gm}$ boric acid. The chemical durability of the prepared composite cement-dust-glaze-ceramics (CDGC) is investigated using high concentrations of $(2,5 \& 8 \mathrm{~N}) \mathrm{HCl}$ acid solutions. CDGC are vitrified by melting for four hours at $1400^{\circ} \mathrm{C} \pm$ $250^{\circ} \mathrm{C}$ depending on the amount of CKD introduced. Specifically, the experimental results indicate that the introduction of CKD in industrial glaze decreases durability. At high $\mathrm{HCl}$ concentrations, the durabilities of the prepared glaze-ceramics are observed to decrease with increasing the percentage of (CKD) until certain limit and almost constancy. The corrosion results are explained according to the ion exchange mechanism and formation or dissociation of the modified depleted layer.
\end{abstract}

Some hollow and jogged areas are observed by SEM which might be interpreted as evidence of local corrosion phenomena. In addition, the $\mathrm{pH}$ values of the leachant solutions are measured. The comparison of hardness for the optimum glaze-ceramic and glaze-ceramic derivatives prepared in this study indicates a degradation $\%$ in their chemical and physical properties depending on the amount $\%$ of CKD introduced. It is observed that the degradation not only depends on the amount of CKD introduced, but also on the strength of the leaching $\mathrm{HCl}$ acid solution. Also, the results show that, the prepared glazes have a surface hardness values ranged from 5.5 to 2.5 in the Mohs scale.

Keywords: CKD waste, New glaze-ceramics, Corrosion and Hardness.

The re-use of materials gained from solid wastes reduces degradation of living environment, which is the initial objective of solid-waste management. In this context, the minimization of huge wastes produced by the cement industry is of great concern in most of the countries. For a sustainable future, it would be imperative to recycle as much as of these wastes as possible, on one hand to alleviate the problem of environmental inconvenience caused by landfills and on 
the other hand to create a supply of inert materials that would meet the environmental laws and industrial policies ${ }^{(1)}$.

Ceramics have come up as a trend to reduce the risks to human and the environment as well as offering the possibility of combining the special properties of conventional sintered glaze-ceramics with the distinctive characteristics of cement-kiln-dust waste. Developing ceramic-glazes demonstrates the advantage of combining various remarkable properties in one material. Ceramic-glazes comprise special low melting type of silicate glasses. For each type of ceramic bare product, it is necessary to develop the corresponding glazes because of the need to match the chemical and physical properties. About 500000 tons of (CKD) wastes are generated during the industrial production of cement. At present, the waste is being deposited in open area where it pollutes the environment. Its utilization will result in significant cost but also the problem of pollution of the environment will be solved.

Glasses are generally chemically stable both in acidic and basic environments. This characteristic feature of glass made vitrification techniques useful for treatment of different wastes ${ }^{(2)}$. However, this method leaves vitreous product requiring disposal. Although these products are chemically inert, it is important to evaluate chemical durability. Exposure of glass to water may at first leach mobile modifier ions followed by the dissolution of glass matrix. These corrosion reactions start from the surface and proceed inwards by diffusion of various ionic species as well as by dissociation of chemical bonds which form glasses. The overall reaction involves two subsequent primary steps; leaching of mobile ions and uniform (or complete) dissolution of the matrix itself ${ }^{(3)}$.

For silicate glasses, alkali leaching kinetics are often described by two limiting stages. In the first stage, alkali leaching proceeds as a function of $\mathrm{t}^{1 / 2}$. In the most commonly used leaching model, this stage is attributed to a simple ion exchange process in which $\mathrm{H}^{+}$or $\mathrm{H}_{3} \mathrm{O}^{+}$from the leachate diffuses into the glass, and alkali cations diffuse out. The rate of interdiffusion is often equated with the self-diffusion coefficient of the slowest moving cation in bulk glass. The common explanation for the second stage of leaching, where alkali leaching is linear with time, is that the leached layer eventually becomes as thicker as the dissolution rate of the silicate network, resulting in uniform glass dissolution, and a leached layer which reaches a constant steady state thickness as a function of time $^{(4)}$.

This paper presents results regarding the corrosion behavior of the CDGC soaked in high concentrated $\mathrm{HCl}$ solution. In this work, chemical durability and hardness properties of glazes doped CKD derivatives have been studied with the focus on the principal role of CKD to modifying the chemical durability of the commercial glaze and topography of the surface. Finally, this study aims to know how the addition of CKD to the industrial glaze enables the CDGC to resist high concentrated $\mathrm{HCl}$ solutions.

Egypt. J. Chem. 53, No.1 (2010) 
Glaze preparation

\section{Experimental}

Tables 1 and 2 show the composition of CKD and prepared industrial glazedceramics, respectively. CKD used in the experiments was sampled from BeniSuef Company, while glaze was from Shiny Company. The chemical compositions for both CKD and industrial glaze were analyzed with a combination of inductively coupled plasma (ICP) and X-ray fluorescence spectroscopy (XRF). The new glaze batches were formulated as shown in Table 3. The cement dust was added with increasingly amounts in the different batches from $10 \%$ to $50 \%$. The batches were melted individually in platinum crucibles $2 \% \mathrm{Rd}$ at $\sim 1400-1150^{\circ} \mathrm{C}$ for $5 \mathrm{hr}$ depending on the $\mathrm{CKD} \%$ and were stirred frequently for complete homogeneity until reasonably free from air bubbles.

TABLE 1. Analysis of portland cement and CKD (Wt.\%).

\begin{tabular}{|c|l|l|l|c|c|c|c|c|c|l|l|}
\hline Constituents & $\mathbf{C a O}$ & $\mathbf{S i O}_{2}$ & $\mathbf{A l}_{2} \mathbf{O}_{3}$ & $\mathbf{F e}_{2} \mathbf{O}_{3}$ & $\mathbf{M g O}$ & $\mathbf{K}_{2} \mathbf{O}$ & $\mathbf{N a}_{2} \mathbf{O}$ & $\mathbf{S O}_{3}$ & Cl & I.L. \\
\hline Portl. Cem. & 63.77 & 20.36 & 5.33 & 3.97 & 2.1 & 0.14 & 0.48 & 2.72 & 0.03 & 19.10 \\
\hline CKD & 45.14 & 11.45 & 3.22 & 1.88 & 0.53 & 3.73 & 2.72 & 5.14 & 2.59 & 23.60 \\
\hline
\end{tabular}

TABLE 2. Frit composition for the industrial glaze (weight \%).

\begin{tabular}{|c|c|c|c|c|c|c|c|c|}
\hline Borax & $\mathbf{B}_{\mathbf{2}} \mathbf{O}_{\mathbf{3}}$ & Albite & $\mathbf{Z n O}$ & Dolomite & $\mathbf{C a C O}_{3}$ & Zircon & Sand & $\mathbf{N a}_{2}\left(\mathbf{C O}_{3}\right)$ \\
\hline 11.418 & 27.71 & 12.026 & 0.78 & 3.634 & 8.992 & 13.929 & 18.788 & 2.722 \\
\hline
\end{tabular}

TABLE 3. Cement-dust-glaze (CDG) compositions in weight \%.

\begin{tabular}{|c|c|c|c|}
\hline Glaze notation & Frit & $\mathbf{B}_{\mathbf{2}} \mathbf{O}_{\mathbf{3}}$ & CKD \\
\hline G1 & 90 & 10 & 0 \\
\hline G2 & 80 & 10 & 10 \\
\hline G3 & 70 & 10 & 20 \\
\hline G4 & 60 & 10 & 30 \\
\hline G5 & 50 & 10 & 50 \\
\hline
\end{tabular}

Slabs with dimensions $1 \times 1 \times 0.4 \mathrm{~cm}^{3}$, were shaped in a stainless steel mold and selected on the basis of uniformity of dimensions and freedom from bubbles. The specimens were annealed in an electric furnace at $500^{\circ} \mathrm{C}$ and after soaking for $1 \mathrm{hr}$ were left to cool slowly over-night at a rate of $20^{\circ} \mathrm{C} / \mathrm{hr}$.

\section{Chemical resistance test}

A series of glaze coupons $(1 \times 1 \times 0.2 \mathrm{~cm})$ was placed horizontally in $50 \mathrm{ml}$ polyethylene BD Falcon ${ }^{\mathrm{TM}} 50 \mathrm{ml}$ Conical Tube with Flip Top Cap which allows the etchant solution $(50 \mathrm{ml})$ to completely cover the whole glass surfaces of the specimen and then the tube is tightly closed. The inlet acid solutions $(2,5 \& 8 \mathrm{~N} \mathrm{HCl})$ used in this study were prepared from deionized water plus reagent grade of $\mathrm{HCl}$ acid. The test duration ranged from 1 up to 25 days at room temperature $\left(\sim 25^{\circ} \mathrm{C}\right)$ and, at $100^{\circ} \mathrm{C} \pm 2^{\circ} \mathrm{C}$ from 2 up to $30 \mathrm{hr}$. After complete specified immersion times in each acid solution, samples were cleaned in de-ionized water and left to dry completely in air in a descicator and then accurately weighed. As the etching is affected by surface area, so the relationship between the geometric area of the glass samples and the volume of the solutions was maintained as $\mathrm{S} / \mathrm{V}=0.042 \mathrm{~cm}^{2} / \mathrm{ml}$.

Egypt. J. Chem. 53, No.1 (2010) 


\section{pH measurents}

Outlet fluid $\mathrm{pH}$ was measured immediately after corrosion tests using an Orion Research $(601 \mathrm{~A})$ at $25^{\circ} \mathrm{C}$. Accuracy of measurements was $\pm 0.01 \mathrm{pH}$ unit. Initial (before experiments) solutions were used as standards to minimize matrix defect.

\section{SEM}

Photomicrographs of CDGC samples before and after the corrosion experiments were performed using a JSM- 5400 Scanning electron microscope (SEM). A thin film of gold was previously evaporated on the surface before measurement.

\section{Hardness test (Mohs scratch test)}

Mohs scale of mineral hardness characterizes the scratch resistance of the material in this case the glazed surface. The Mohs scale is based on ten minerals that are all readily available except the last one, diamond (Table 4). The hardness of a material is measured against the scale by finding the softest/hardest mineral that can scratch the material. On the Mohs scale, value between 1-5 are considered soft surface while those values above 5 up to 10 are considered hard surface.

TABLE 4. Hardness of minerals based on Mohs scale .

\begin{tabular}{|c|c|c|}
\hline Mohs Hardness & Minerals & Absolute hardness \\
\hline 1 & Talc $\left(\mathrm{Mg}_{3} \mathrm{Si}_{4} \mathrm{O}_{10}(\mathrm{OH})_{2}\right)$ & 1 \\
\hline 2 & Gypsum $\left(\mathrm{CaSO}_{4} \cdot 2 \mathrm{H}_{2} \mathrm{O}\right)$ & 3 \\
\hline 3 & Calcite $\left(\mathrm{CaCO}_{3}\right)$ & 9 \\
\hline 4 & Fluorite $\left(\mathrm{CaF}_{2}\right)$ & 48 \\
\hline 5 & Apatite $\left(\mathrm{Ca}_{5}\left(\mathrm{PO}_{4}\right)_{3}\left(\mathrm{OH}^{-}, \mathrm{Cl}^{-}, \mathrm{F}^{-}\right)\right)$ & 72 \\
\hline 6 & Orthodase Feldspar $\left(\mathrm{KAlSi}_{3} \mathrm{O}_{8}\right)$ & 100 \\
\hline 7 & Quartz $\left(\mathrm{SiO}_{2}\right)$ & 200 \\
\hline 8 & Topaz $\left(\mathrm{Al}_{2} \mathrm{SiO}_{4}\left(\mathrm{OH}^{-}, \mathrm{F}^{-}\right)_{2}\right)$ & 400 \\
\hline 9 & Corundum $\left(\mathrm{Al}_{2} \mathrm{O}_{3}\right)$ & 1500 \\
\hline 10 & Diamond $(\mathrm{C})$ & \\
\hline
\end{tabular}

The glazed-tile test pieces $(1 \times 2 \times 0.4 \mathrm{~cm})$ were cleaned and dried prior to testing. The prepared test pieces were subjected to scratch using the mineral found in the Mohs scratch test kit. The scratch while using as minimal pressure as possible was done starting with the mineral of lowest hardness value, which is 1 on the Mohs scale and subsequently changed to the next mineral that could inflict or cause scratch to the glazed-tile surface.

\section{Leaching}

\section{Results}

The degree of corrosion in a glaze specimens is calculated from its weight loss $\left(\mathrm{gm} / \mathrm{cm}^{2}\right)$ over time (days). Figures 1-5 show the weight loss for the five studied glazes (G1-G5), respectively as a function of time (1-25 days) when immersed in $2,5 \& 8 \mathrm{~N} \mathrm{HCl}$ solutions at room temperature. Overall weight losses of the glaze are observed to be less in $2 \mathrm{~N} \mathrm{HCl}$ solution compared to the weight loss in 5 or $8 \mathrm{~N} \mathrm{HCl}$ solutions. Also, it can be noticed that, the weight losses 
increase drastically either with increasing immersion times or $\mathrm{HCl}$ concentrations especially at early immersion times (1-10 days). However, with increasing immersion times, there is a swinging in the weight losses depending on the CKD\% as shown in Fig. 3-5. The effect of temperature $\left(100^{\circ} \mathrm{C}\right)$ is presented in Fig. 6 and it is evident that the corrosion increases relatively to the increase of CKD\% (up to $40 \%$ ) and then either decreases or remains nearly unchanged (50\% CKD) when the glaze samples are immersed in 2 or $5 \mathrm{~N} \mathrm{HCl}$, respectively. The effect of immersion times (6-30 hrs) for glazes 3 and 5 when soaked in 2 or $5 \mathrm{~N}$ $\mathrm{HCl}$ are illustrated in Fig. 7 and 8, respectively. From these figures it can be noticed that the corrosion rate is slow at the early immersion times (6-18 hr) and then becomes faster afterwards.

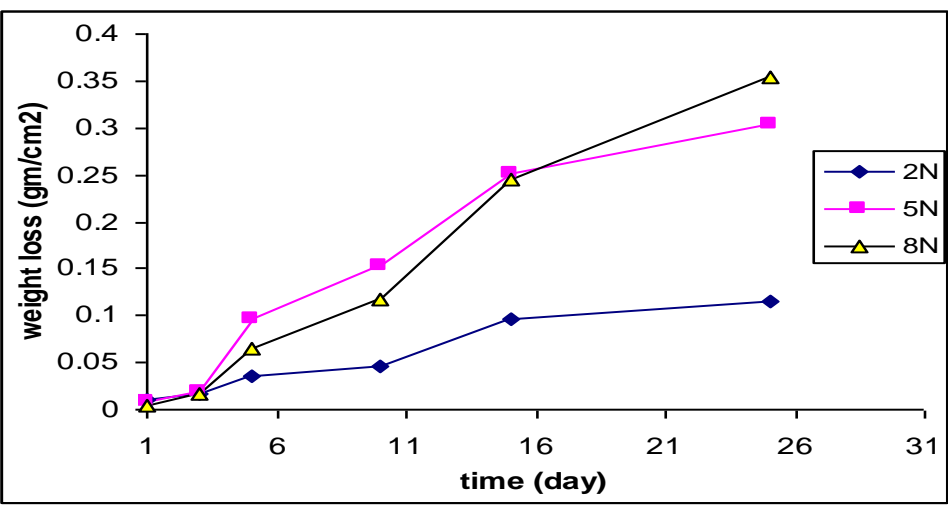

Fig. 1. Effect of immersion time (days) and $\mathrm{HCl}$ concentrations on the durability of glaze (G1) at room temperature.

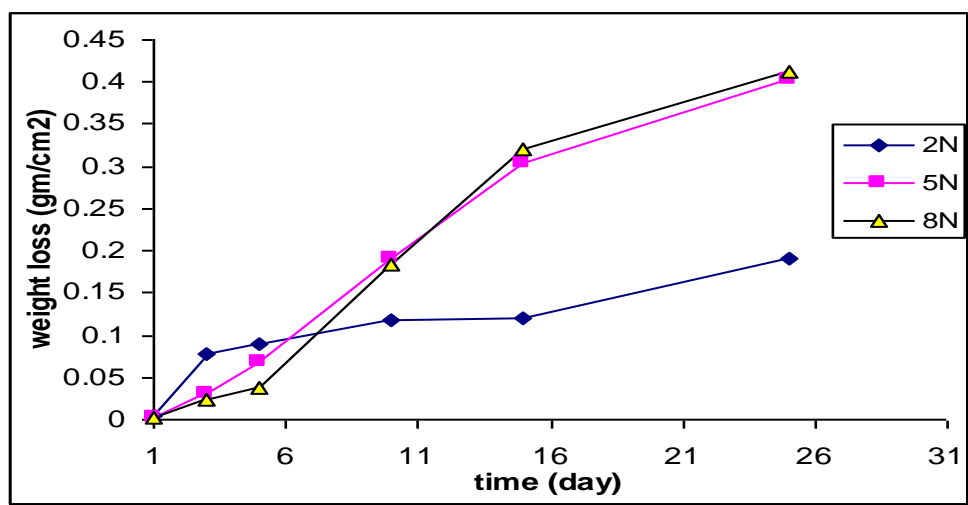

Fig. 2. Effect of immersion time (days) and HCl concentrations on the durability of glaze (G2) at room temperature. 


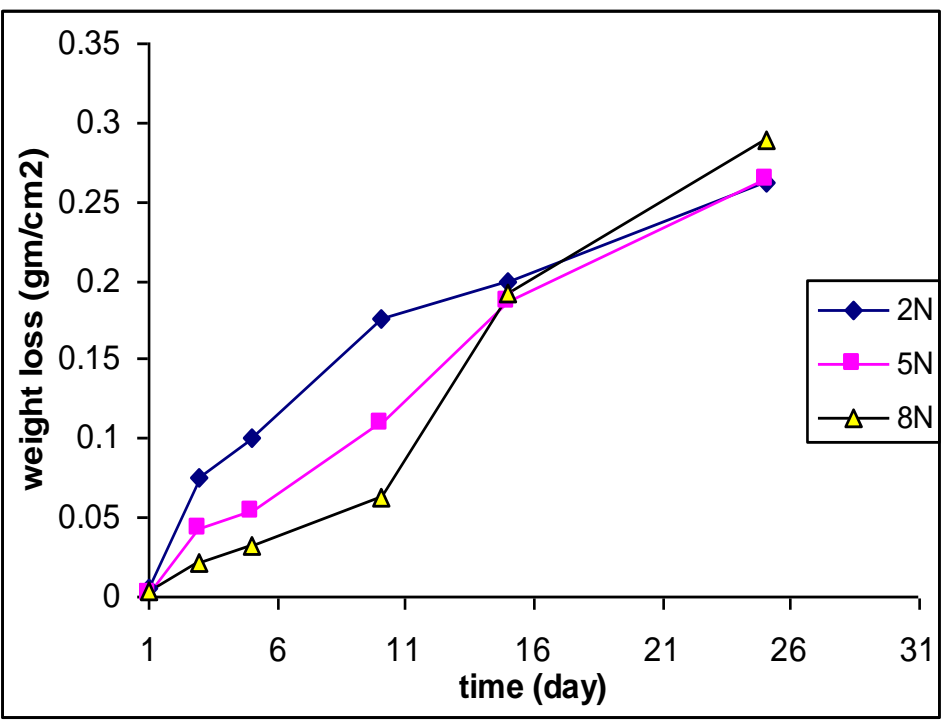

Fig. 3. Effect of immersion time (days) and $\mathrm{HCl}$ concentrations on the durability of glaze (G3) at room temperature.

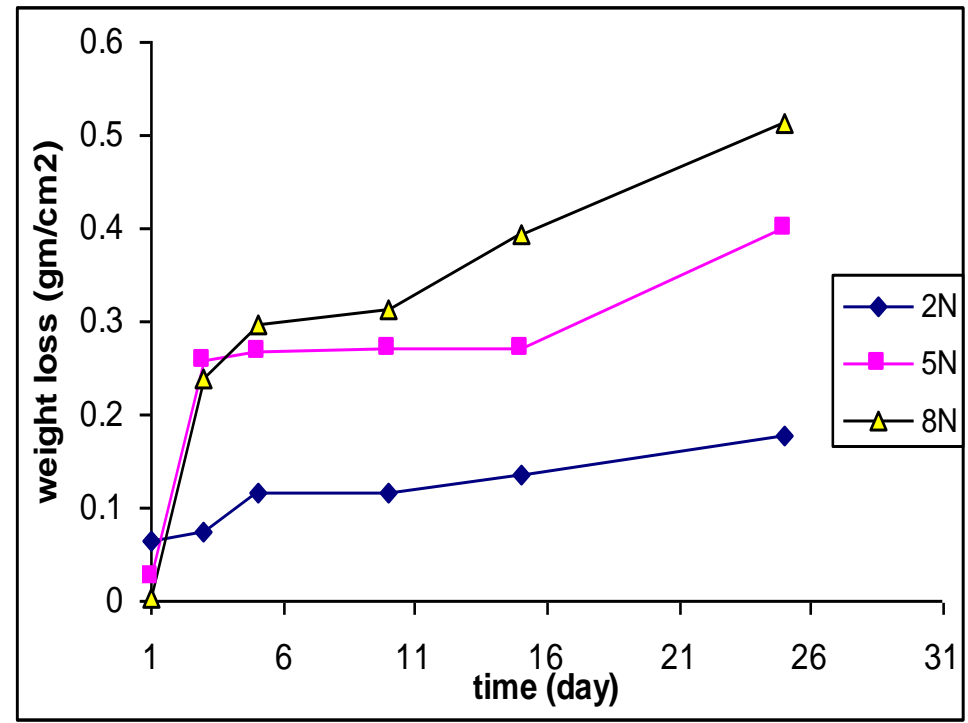

Fig. 4. Effect of immersion time (days) and HCl concentrations on the durability of glaze (G4) at room temperature.

Egypt. J. Chem. 53, No.1 (2010) 


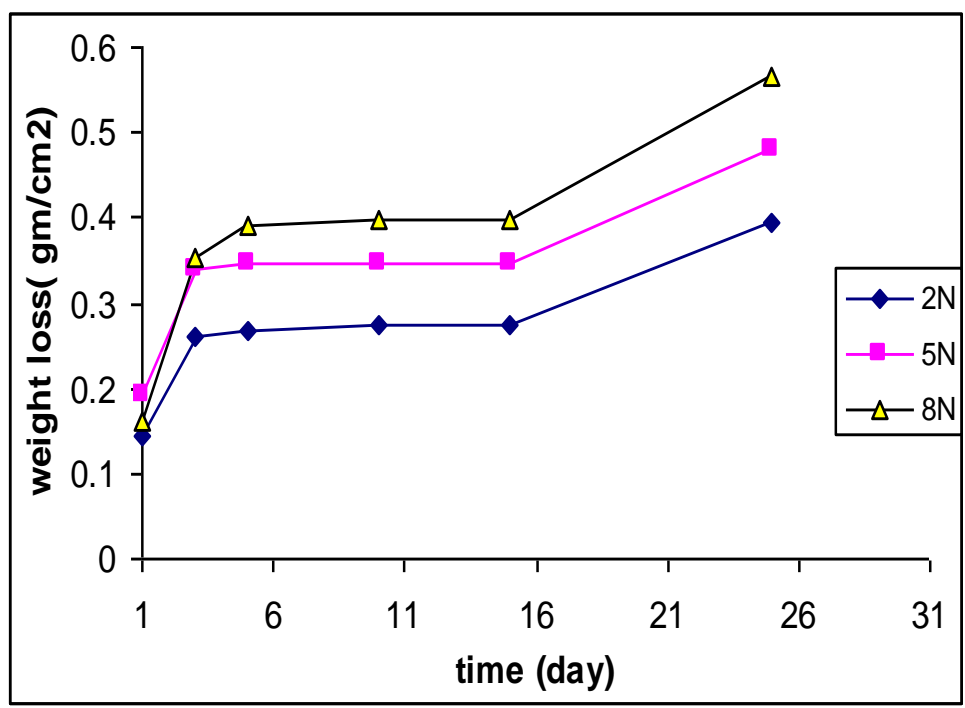

Fig. 5. Effect of immersion time (days) and HCl concentrations on the durability of glaze (G5) at room temperature.

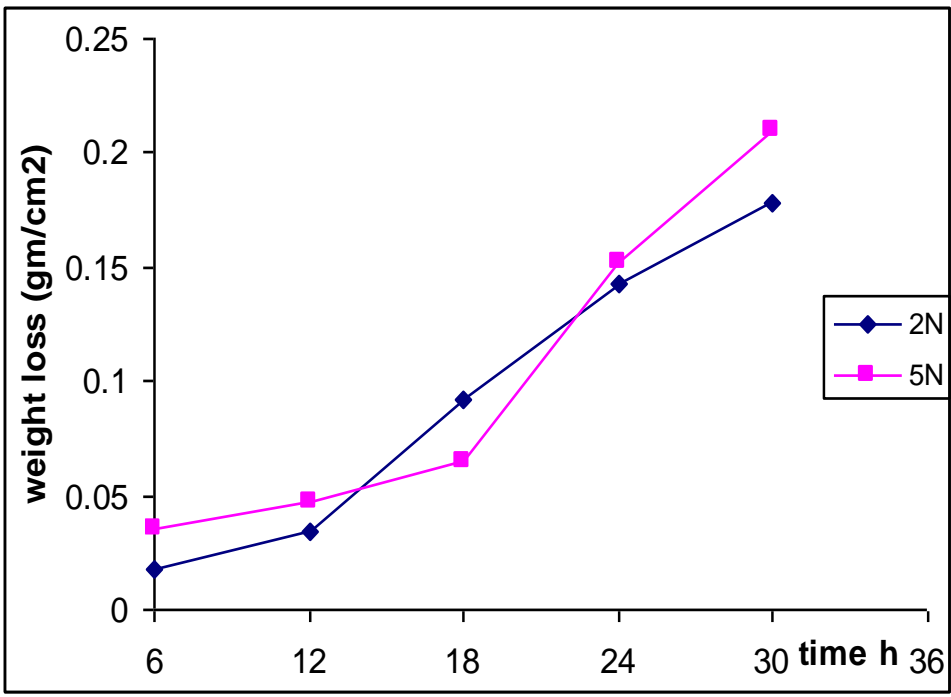

Fig. 6. Effect of immersion time (hours) and $2,5 \mathrm{~N} \mathrm{HCl}$ concentrations on the durability of glaze $(\mathrm{G3})$ at $100^{\circ} \mathrm{C}$. 


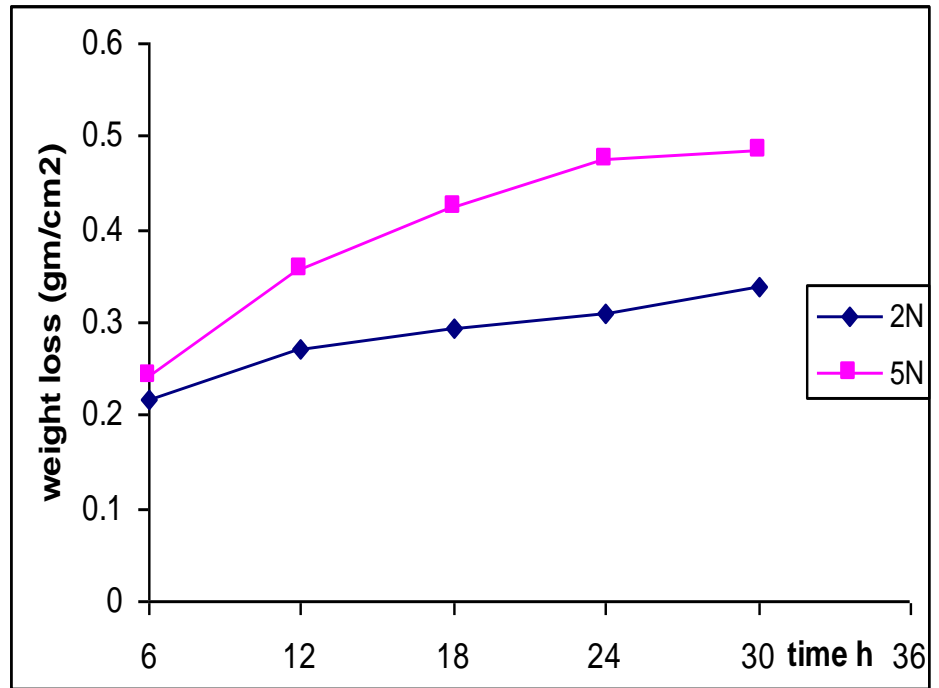

Fig. 7. Effect of immersion time (hours) and 2,5N $\mathrm{HCl}$ concentrations on the durability of glaze (G5) at $100^{\circ} \mathrm{C}$.

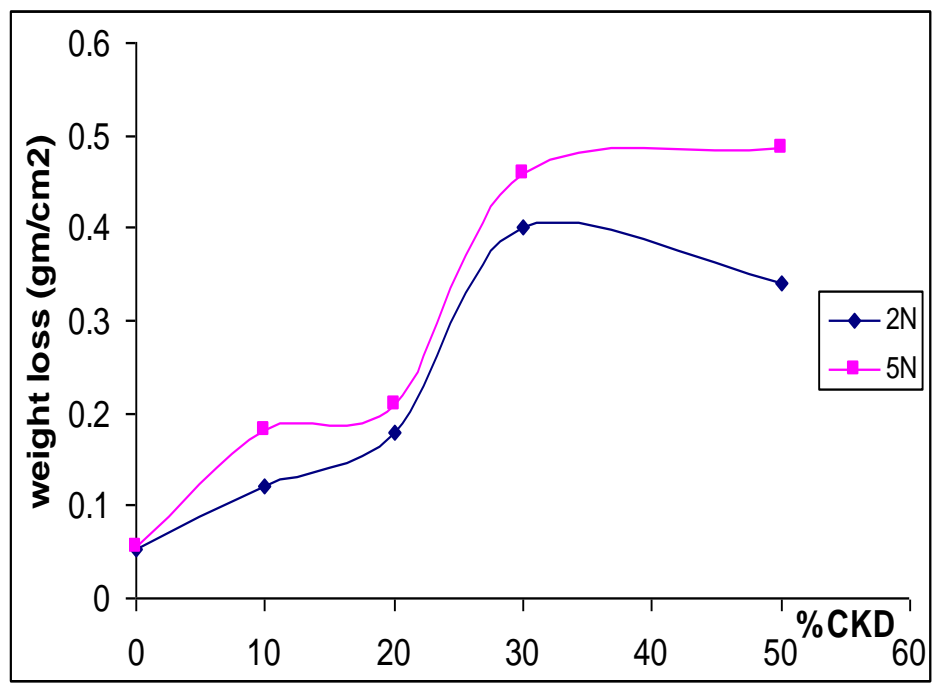

Fig. 8. Effect of glaze compositions and $2,5 \mathrm{~N} \mathrm{HCl}$ concentrations on the durability of glaze $(\mathrm{G3})$ at $100^{\circ} \mathrm{C}$.

Egypt. J. Chem. 53, No.1 (2010) 
pH measurements

Figure 9 reveals that the $\mathrm{pH}$ values for the leachate relatively increase as the $\mathrm{CKD} \%$ or the strength of $\mathrm{HCl}$ solutions increases. Moreover, the same trend is observed when the temperature of $\mathrm{HCl}$ solutions is raised to $100^{\circ} \mathrm{C}$ or the strength of $\mathrm{HCl}$ solution is decreased (Fig. 10).

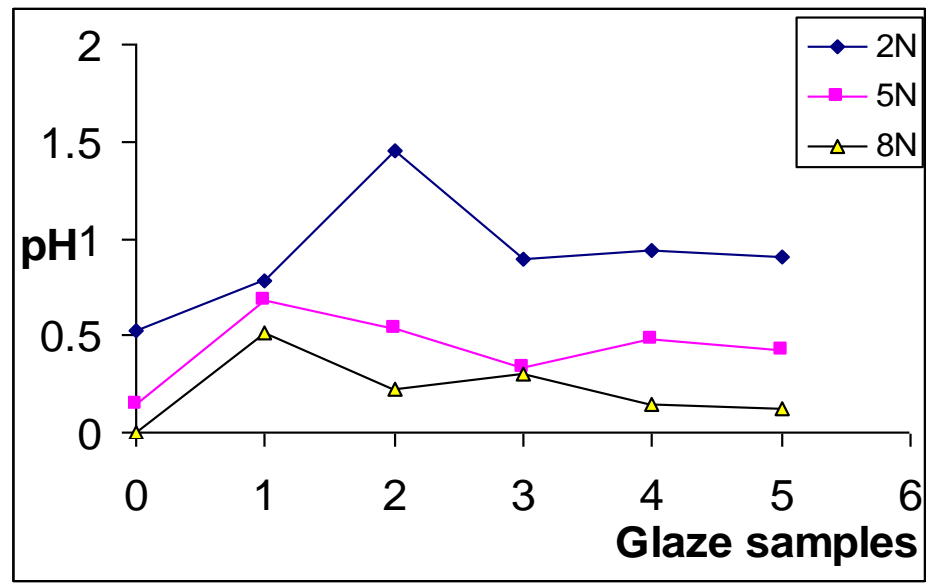

Fig. 9. Effect of glaze compositions and $2,5,8 \mathrm{~N} \mathrm{HCl}$ concentrations on the pH value at room temperature.

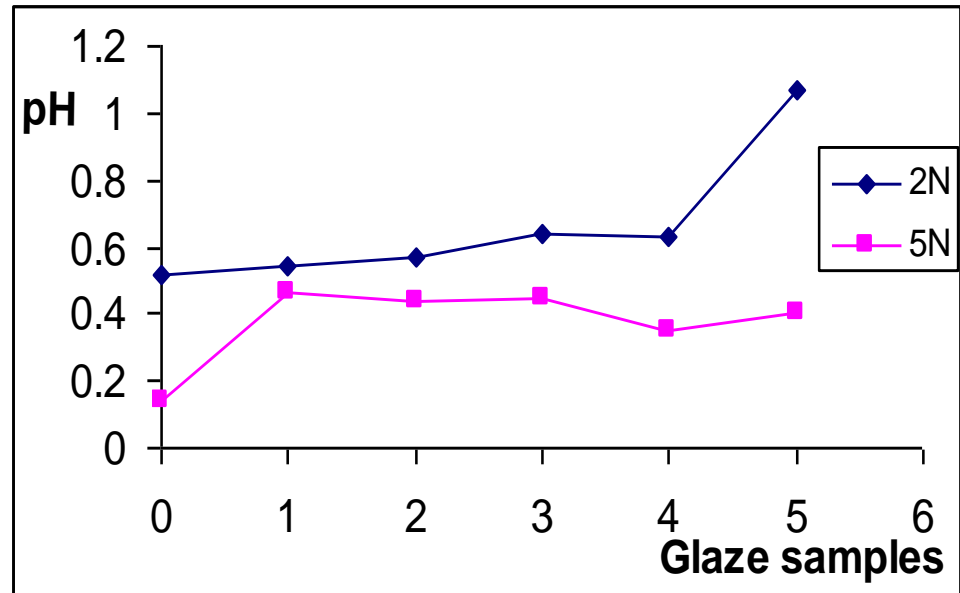

Fig. 10. Effect of glaze compositions and $2,5,8 \mathrm{~N} \mathrm{HCl}$ concentrations on the pH value at $100^{\circ} \mathrm{C}$. 


\section{Hardness}

Figures 12-15 show the results of Mohs scratch test on the 5 prepared CDGC samples after been immersed in different $\mathrm{HCl}$ acid solutions for different immersion times. All the five specimens were found to be scratched by the mineral fluorite, which on the Mohs scale has a hardness of 6 (Table 4). The values of absolute hardness for the corroded glaze samples $(\mathrm{G} 1, \mathrm{G} 2, \mathrm{G} 3)$ are illustrated in Fig. 12 -14. It can be noticed that, the hardness generally decreases gradually with increasing $\mathrm{HCl}$ concentrations or the immersion times. The decrease is sharply in the early stages of corrosion and then there is some sort of stability. In addition, Fig. 15 shows the effect of different $\mathrm{CKD} \%$ on the hardness values after been soaked in $5 \mathrm{~N} \mathrm{HCl}$ solution for 25 days. It is obvious that, the hardness values fall down rapidly for G5 at the early immersion times (up to 10 days) followed by a constancy in the hardness values except that, the decrease in hardness values is related oppositely to the CKD\%. Generally, in our case the prepared glazes have a surface hardness $<5.5$ and $>2.5$ which are considered to be normal and soft surfaces.

\section{Discussion}

Due to the rapid increase in the quantities of solid wastes, affecting both public health and environment, efficient and sustainable solid waste-management must be considered as the most pressing issue on the agenda of developing countries and governments worldwide.

\section{Corrosion}

Chemical durability of glazes is usually discussed in terms of durability of the surface glassy phase in accordance with the same terms as with that occurring with glasses. Glasses react in acidic environment by ion exchange or preferentially substitution of alkali ions by hydrogen ions. In alkaline environments, the network structure of glass is continuously attacked and destroyed by hydroxyl attack $^{(5-9)}$. Glaze-ceramic materials are considered as polycrystalline silicate solids containing a glassy phase and possess a valuable combination of the favorable properties of both glasses and ceramics ${ }^{(10)}$.

This influence of different oxides on the durability of glasses and glossy glazes is well understood. However, chemical resistance of glazes consisting of one or several crystalline phases embedded in a glassy matrix has not been fully and widely studied. Wollastonite and anorthite crystals devitrified from a frited glaze have been reported to be attacked by acidic solutions ${ }^{(11)}$. Wollastonite crystals in fast-fired raw glazes are attacked by acidic and also slightly alkaline water solutions ${ }^{(12,13)}$. The formation of crystalline phases in traditionally fired glazes takes place according to the equilibrium reactions and is controlled by the total oxide composition of the glaze. However, in a modern fast-firing process of floor tiles, the short firing cycle of $60-90 \mathrm{~min}$ restricts the extent of raw materials $^{(14)}$. The surface is often unmature and its chemical and mechanical properties are incompletely understood ${ }^{(15)}$. 

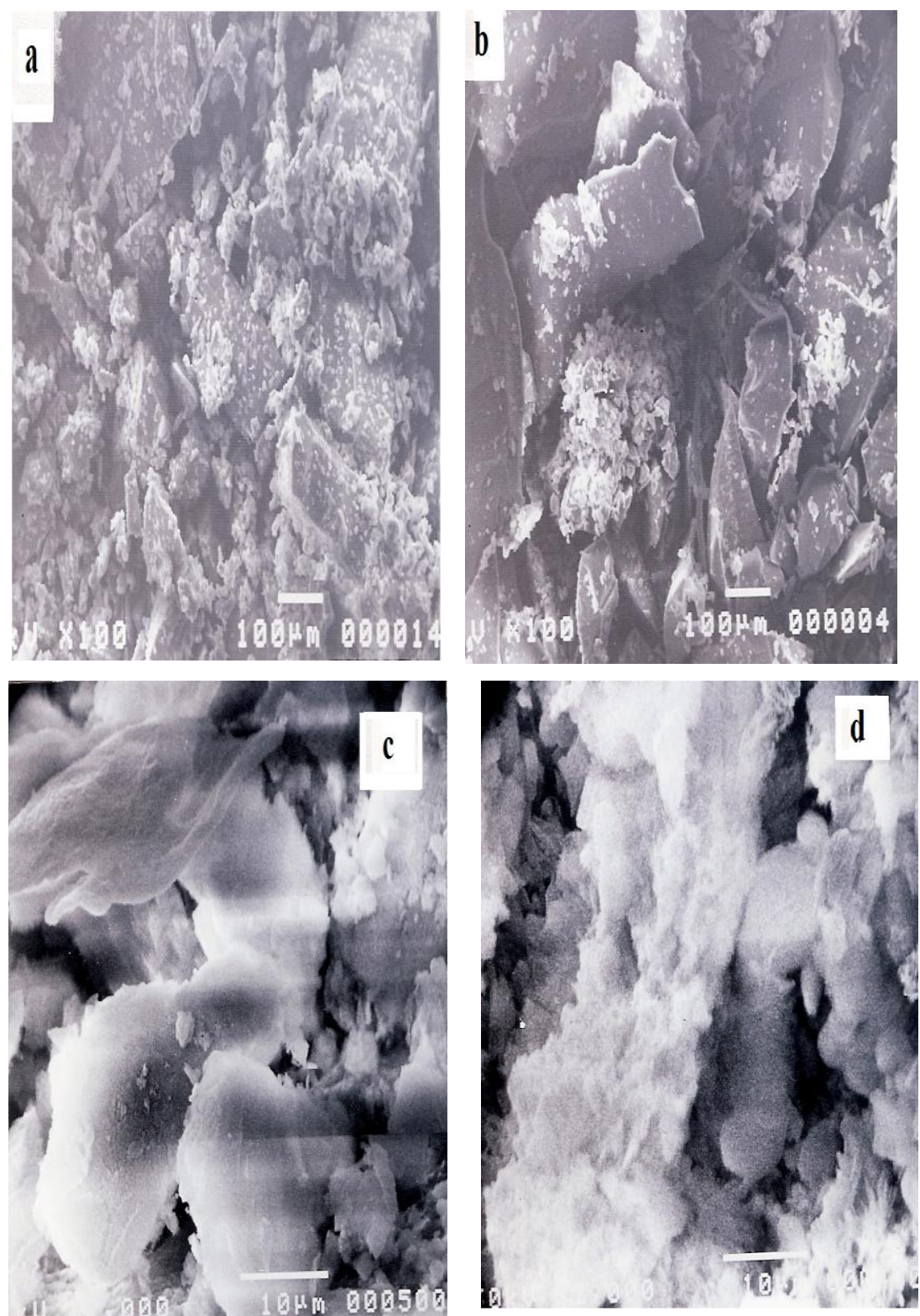

Fig. 11. SEM of glaze G3 before and after soaking in $2,5,8 \mathrm{~N} \mathrm{HCl}$ concentrations for 25 days at room temperature. 


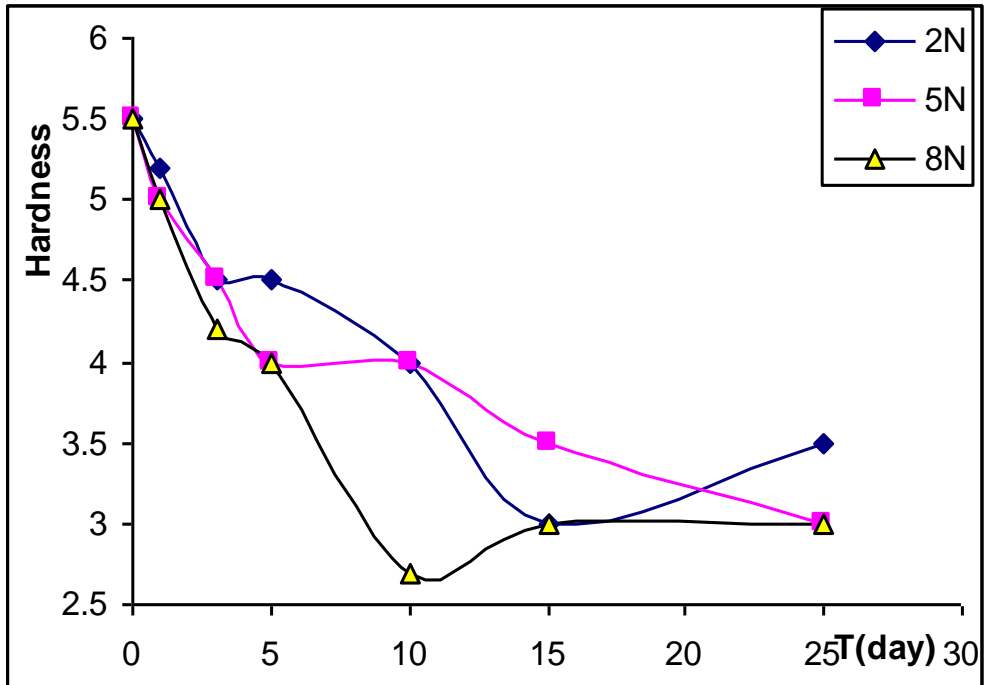

Fig. 12. Effect of immersion time (days) and $\mathrm{HCl}$ concentrations on the absolute hardness of glaze (G1) at room temperature.

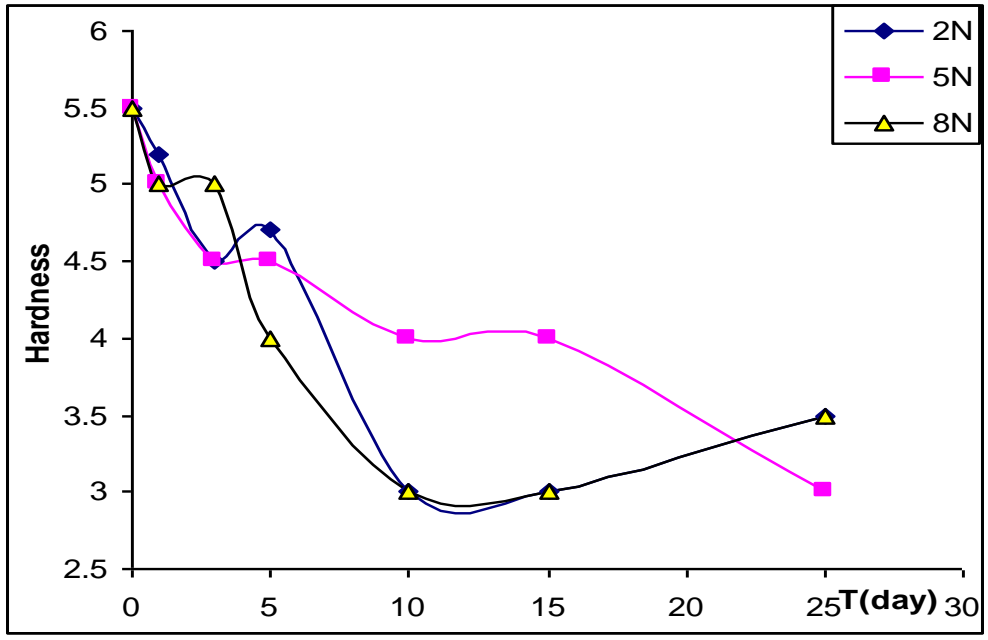

Fig. 13. Effect of immersion time (days) and $\mathrm{HCl}$ concentrations on the absolute hardness of glaze (G2) at room temperature. 


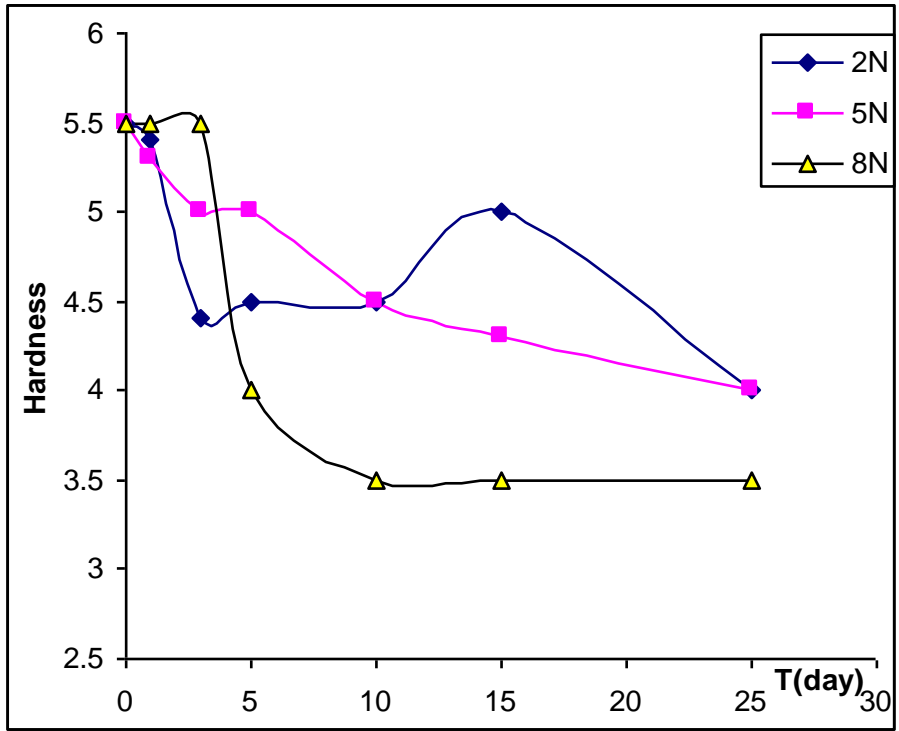

Fig. 14. Effect of immersion time (days) and HCl concentrations on the absolute hardness of glaze (G3) at room temperature.

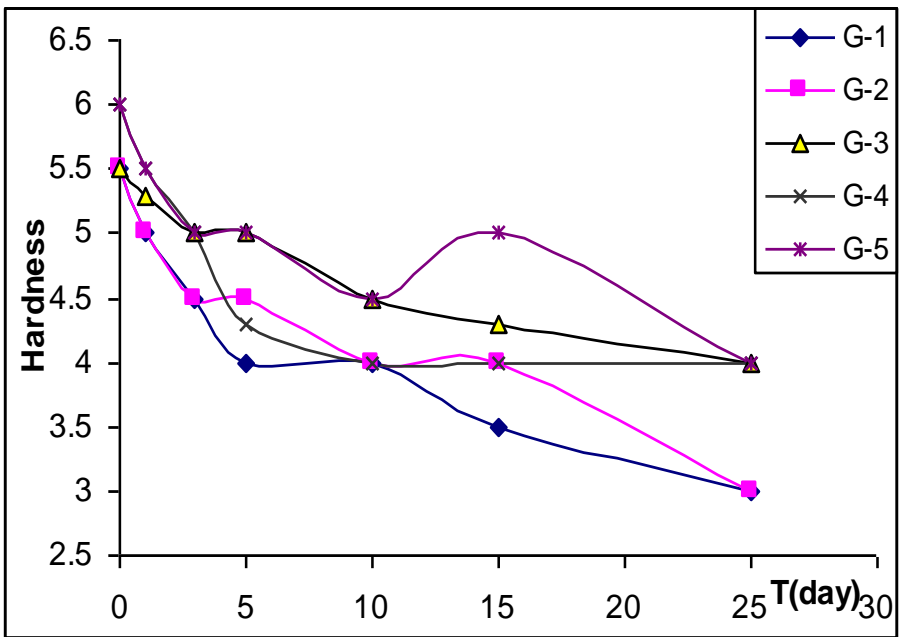

Fig. 15. Effect of glaze compositions and $5 \mathrm{~N} \mathrm{HCl}$ concentration on the absolute hardness at room temperature. 
The leaching results (Fig.1-5) can be explained according to the postulations given in previous studies ${ }^{(10)}$ which have shown that when sodium borosilicate glasses dissolve in acidic solutions, sodium and boron are selectively removed to produce hydrosilicate leached layers. In all cases, the structure of the leached glass is substantially different from that of the parent glass. It can be assumed that ${ }^{(16)}$ some of the nonbridging oxygen (NBO) sites are converted into silanol ( $\mathrm{SiOH})$ groups via the $\mathrm{H}^{+} \leftrightarrow \mathrm{Na}^{+}$ion exchange:

$$
\equiv \mathrm{Si}-\mathrm{O}^{-} \mathrm{Na}^{+}+\mathrm{H}_{3} \mathrm{O}^{+} \rightarrow \equiv \mathrm{Si}-\mathrm{OH}+\mathrm{Na}^{+}+\mathrm{H}_{2} \mathrm{O}
$$

The large decrease in concentration of NBO`s after ion exchange demonstrates that silanol groups in leached glass react with each other to form new Si-O-Si bonds via reaction such as:

$$
\equiv \mathrm{Si}-\mathrm{OH}+\mathrm{HO}-\mathrm{Si} \equiv \rightarrow \quad=\mathrm{Si}-\mathrm{O}-\mathrm{Si}+\mathrm{H}_{2} \mathrm{O}
$$

If reaction (2) was to go to completion, the product would be amorphous silica and water.

The leaching results clearly demonstrate that (CDGC) undergo some structural changes during leaching in high concentrated $\mathrm{HCl}$ aqueous solutions. Published results concerning the chemistry of silica indicate the formation of silanol groups during selective leaching promote the observed structural changes $^{(17)}$. Silanol groups promote the hydrolysis of adjacent Si-O-Si bonds, leading to depolymerization and dissolution of the silicate network. Simultaneously silanol groups exhibit a strong tendency to condense with each other, reforming $\mathrm{Si}-\mathrm{O}-\mathrm{Si}$ bonds and promoting repolymerisation of the network causing false stability in durability observed in the interval times (5-15 days) indicating the repolymerisation of silicate network after leaching.

The fact that all the four glazes (G2-G5) have almost identical concentrations of both silanol groups and fourfold rings suggests that the structure of the hydrosilicate phases produced by leaching under acid conditions is independent of the structure of the parent glass. It appears that the initial network structure is broken down and reconstructed and at last time is completely dissociated (Fig.5) during leaching with high $\mathrm{HCl}$ concentration $(8 \mathrm{~N})$. For borosilicate glasses, another important reaction leading to the formation of silanols is the hydrolysis of Si-O-B. It was suggested ${ }^{(16)}$ that in acidic solutions hydrolysis of Si-O-B and B-O-B bonds (with either trigonal or tetrahedral borons) involves the electrophilic attack of protons on bridging oxygens (Reaction 3 ).

Reaction 3 explains why boron leaching is promoted in acidic solutions and why acidic solutions promote the conversion of fourfold boron sites to threefolds sites. Dissolution data suggest that the $\mathrm{pH}$ below which the bridging oxygen is protonated and subsequently hydrolyzed for both $\mathrm{Si}-\mathrm{O}-\mathrm{B}$ and $\mathrm{B}-\mathrm{O}-\mathrm{B}$ bonds is near $4^{(16)}$. 


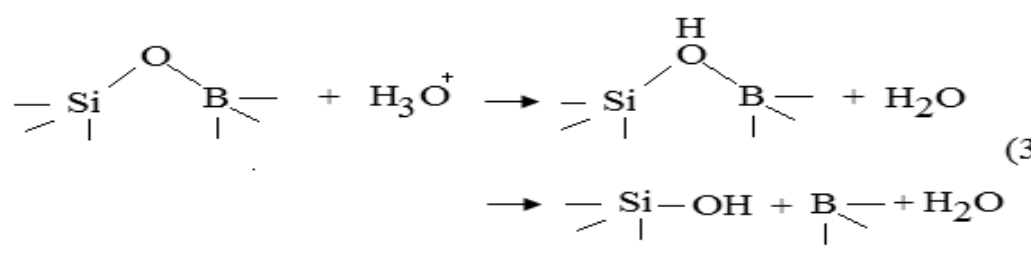

The network is transformed from a homogeneous diffusion barrier to a porous aggregate colloidal silica particles in which diffusion is rapid and not contribute to the generation of large tensile stress in leached layers, leading to crazing and spalling $^{(18)}$. However, increasing immersion time up to 25 days leads to fast and high dissolution due to the detach of leached layer (Fig. 4\&5) and complete dissociation takes place for glazes G4 and G5.

The high dissolution observed with high temperature as represented in Fig. 6,7 and 8 can be explained as follows, at such high temperature $\left(100^{\circ} \mathrm{C}\right)$, the convection currents promote ease ionic contacts and diffusion and ionization of further protons from the weakly dissociated acid replacing the consumed ones which leads to the observed continuous increase in corrosion and the high temperature promotes high dissolution.

The observed constancy or decrease in the weight loss when CKD exceeds $30 \%$ as observed in Fig. 8 can be realized and interpreted by assuming that the increase of $\mathrm{CKD}$ introduces much $\mathrm{CaO}$ and other constituents which may reach constant solubility with $\mathrm{HCl}$ and saturation with less ability for further attack.

pH data

The effect of $\mathrm{HCl}$ concentrations on the $\mathrm{pH}$ values either at room temperature or at $100^{\circ} \mathrm{C}$ is seen in Fig. 9 and 10 , respectively. The $\mathrm{pH}$ appears to behave in a contradictory manner to that described for the dissolution. In other words, the high acidity of the solutions the greater the $\mathrm{pH}$ values (i.e. becomes more basic). This increase in $\mathrm{pH}$ values is assumed to increase the attack by $\mathrm{HCl}$ leading to high running and dissolution of alkalies from glazes to the leachant which form hydroxides causing the increase in $\mathrm{pH}$ values. Also, from these figures it is observed that the $\mathrm{pH}$ values increase when the $\mathrm{CKD} \%$ exceeds $30 \%$ and this is due to the presence of $\mathrm{K}_{2} \mathrm{O}$ and $\mathrm{CaO}$ which form $\mathrm{KOH}$ and $\mathrm{Ca}(\mathrm{OH})_{2}$.

\section{SEM}

Micrographs of glaze surface (G3) before and after soaking in 2, 5 and $8 \mathrm{~N} \mathrm{HCl}$ solutions for 25 days have been shown in Fig. 11. The images are taken of the same surfaces and at identical locations of the surface line profile given in Fig.11. From these images grey holes are observed in the surface structure. After soaking in $2 \mathrm{~N}$ $\mathrm{HCl}$ solution, these holes were partly dissolved and residual crystals were assumed to be nucleated. The crystals are seen in the $5 \mathrm{~N} \mathrm{HCl}$ surface as tiny peaks and after soaking, holes can be observed instead. After soaking in $8 \mathrm{~N} \mathrm{HCl}$, clear changes in micro-roughness of the surface can be verified. This indicates that the increase in 
micro-roughness caused by selective dissolution of the surface is the main reason for the observed differences in softness degree.

\section{Hardness}

It had been reported ${ }^{(19)}$ that, the glaze portion has a leached layer after basic $(\mathrm{pH}=12)$ dissolution but not after acidic $(\mathrm{pH}=1)$ dissolution. Ion exchange during dissolution may cause the formation of $\mathrm{M}-\mathrm{OH}$ and hence cracking of a leached layer ${ }^{(18,20)}$. Alternatively, the residual stress of the glaze due to devitrification and/or cooling may account for the cracking of a leached layer during dissolution. Drying may cause further cracking of this layer analogous to the case of gel drying ${ }^{(21,22)}$.

It is well known that silicate glasses are generally brittle ${ }^{(23)}$. Their stress intensity factor (SIF) is very low, but the actual situation is even worse for glass in ambient conditions, the tip of a surface crack undergoing a SIF of half the critical value, actually is slowly running. The crack speed does not depend on the environment; it increases sharply with SIF but levels off at some characteristic speed. As the strength of glass is controlled by the size of flaws, the fatigue effect is related to the growth of cracks (stress corrosion) during aging in the given environment, under load. Also, the stress corrosion issue requires a careful control of the residual stress.

Our results (Fig. 12 -14) demonstrate that there is a decrease in the hardness values in the early periods of immersion times (up to 10 days) followed by a stability in the hardness values. This behavior is due to the progressive alkaline leaching out of the glass, and that this change in the chemical composition at the tip of the crack is responsible for the fatigue limit rather than a geometrical change (blunting).

The constancy of hardness values (Fig. 12 - 14) after long immersion time (10-25 days), can be assumed to the formation of silanol groups which can be associated with depolymerization and repolymerisation reactions involving the silicate network.

It was suggested that ${ }^{(16)}$, the extent of network repolymerization and the nature of the leached glass structure are controlled in large part by the concentration and distribution of silanol groups created in the glass during leaching. Then, it is possible to make predictions concerning how the glass composition, structure and solution chemistry should influence the repolymerisation process and leaching kinetics. In addition, the ease with which the network will repolymerize should increase as the number of silanols created during leaching increases. No polymerization should be observed for fused silica and glasses with a high silica content should be resistant to repolymerisation while alkali silicate with a high alkali content should be very susceptible to repolymerisation. Moreover, alkali aluminosilicate or borosilicate should not undergo repolymerisation in the neutral $\mathrm{pH}$ regime, but should undergo repolymerisation below $\mathrm{pH} 4$ where selective leaching of $\mathrm{Al}$ or $\mathrm{B}$ leads to the formation of silanols and this is our case.

Egypt. J. Chem. 53, No.1 (2010) 
Referring to Fig. 15, showing the successive increase in hardness (G1 $\rightarrow$ G5) and this increase is relative to the amount of CKD added which is responsible for the hardness characteristic of the glaze due to its high content of $\mathrm{CaO}, \mathrm{MgO}$ and $\mathrm{Fe}_{2} \mathrm{O}_{3}$. In addition, the composition of the glazes in these samples has relatively high content of zircon and dolomite.

\section{Conclusion}

It can be concluded that CKD waste has potential to be used in the preparation of new commercial industrial glazes. The amount of CKD utilized in the glaze formulation can reach up to $50 \%$. Our results indicate that, the CKD affect the melting temperature, increasing CKD\% lowers the melting temperature. The chemical corrosion is markedly degraded due to high concentrated $\mathrm{HCl}(2,5 \& 8 \mathrm{~N})$, but even with these concentrations the new prepared glazes exhibit resistance for these concentrations especially G2 and G3 and improvement of hardness is relative to $\mathrm{CKD} \%$. Finally, experiments on the CDGC enable the extent to which the CKD matrix affects mineral dissolution to be assessed. A leached layer is assumed to be produced under extreme acidic dissolution $(8 \mathrm{~N}=8 \mathrm{~N})$ of the present glaze, because a high dissolution may interfere between both the adsorption of cations and the reconstruction of the surface.

Hence based on these observations, the CKD glazes are suitable to be used for glazing wall tiles which are not subjected to high pressure. In addition, these glazes can also be used for glazing table wares. The possibility of using glazes with a high CKD content (10-50\%) facilitates the use of cheap materials containing calcium and iron compounds and carbonates.

\section{References}

1. Francis, A.A. and Youssef, N.F., Scandinavian J. Metallurgy, 33, 236 (2004).

2. Park, Y.J. and Heo, J., Waste Management, 24, 825 (2004).

3. Varshneya, A.K., Fundamental of Inorganic Glasses, Academic Press, New York (1993).

4. Houser, C.A., Herman, J.S., Tsong, I.S.T. and White, W.B., J.Non-Cryst.Solids, 41, 89 (1980)

5. Eppler, R. and Eppler, D., J.Am. Ceramic Society, Ohio (2000).

6. Carlson, R., Korrosion Av Glasyrer, 99-3tk, Swedish Ceram.Institute (1999).

7. Eppler, R., In : Corrosion of glass, Ceramics and Ceramics Superconductors, Clark, D.E., Zoitos (Ed.), Noyes Publications, New Gersey (1992).

8. Hench, L. and Clark, D.E., J.Non-Cryst.Solids, 28, 83 (1978).

Egypt. J. Chem. 53, No.1 (2010) 
9. Scholze H., Glas. Natur, Struktur Und Eigenschaften, Zweite Auflage, SpringerVerlag, Berlin (1977).

10. Ezz-Eldin, F.M. and Nageeb, W.M., Ind.J.Pure \& Appl.Phys. 39, 514 (2001).

11. Escardino, A., Amoros, J.L., Gozalbo, A., Orts, M.J., Lucas, F. and Belda, A., Qualier 2002 in Proc. of VII World Congress on Ceramic Tile Quality, Castellon, Spain, Vol. I. p. 201(2002).

12. Kronberg, T., Hupa, L. and Froberg, L., Key Eng.Mater., 264-268, 1565 (2004).

13. Vane-Tempest, S., Kronberg, T., Froberg, L. and Hupa, L., Qualier, 2002, in Proc. of VII World Congress on Ceramic Tile Quality, Castellon, Spain, Vol. I. p. 155(2002).

14. Froberg, L., Vane-Tempest, S. and Hupa, L., Qualier, 2002, in Proc. of VII World Congress on Ceramic Tile Quality, Castellon, Spain, Vol. I. p. 143(2002).

15. Hupa, L., Bergman, R., Froberg, L., Vane-Tempest, S., Hupa, M., Kronberg T., Leinoen, E. and Sloberg, A., Surface Science, 584, 113 (2005).

16. Bunker, B.C., Tallant, T., Headley, T.J., Turner, G.L. and Kirkpatric, R.J., Phys.Chem. Glasses, 29 (3), 106 (1988).

17. Iler, R.K., The Chemistry of Silica, John Willey \& Sons, New York (1976).

18. Bunker, B.C., Arnold, G.W., Beauchamp, E.K. and Day, D.E., J.Non-Cryst. Solids, 58, 295 (1983).

19. Wu, H.F., Lin, C.C. and Shen, P., J.Non-Cryst.Solids, 209, 76 (1997).

20. Casey, W.H. and Bunker, B.C., In: Mineral-Water Interface Geochemistry, M.F. Hochella and A.F. White (Ed) (Mineralogical Society of America, Washington, D.C.), p. 397 (1990),

21. Ulrich, D.R., J.Non-Cryst.Solids, 100, 174 (1988).

22. Scherer, G.W., J.Non-Cryst.Solids, 100, 77 (1988).

23. Doremus, R.H., Glass Science, $2^{\text {nd }}$ ed., Willey Interscience Publications, NY (1994).

(Received 13/12/2009;

accepted $12 / 10 / 2010)$ 


\title{
دراسة التأكل للجليز السيراميكى المخلوط بتراب الاسمنت المغمور فى حامض الهيدروكلوريك المركز الهير المئ
}

\author{
فزج أحمد عيسى ، تامر داود عبدالعزيز"، محمد رمضان زكريا** وفتحى محمود

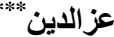 \\ قسم الكيمياء - كلية العلوم - جامعة المنوفية - المنوفية ، "جامعة أكتوبر للآداب

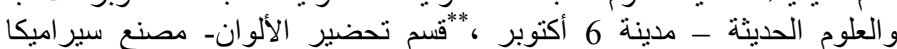 \\ مارسيلياو و***المركز القومى لعلوم وتكنولوجيا الإشعاع - القاهرة - مصر.
}

تهذف الدراسة الى قياس مقدار التأكل الناتج من عينات الجليز السير اميكى المخلوط

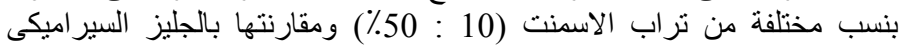

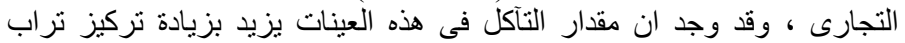

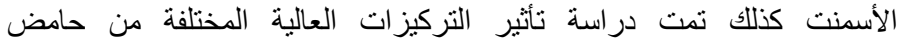

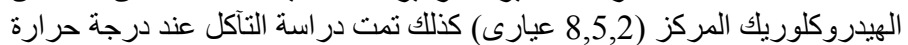

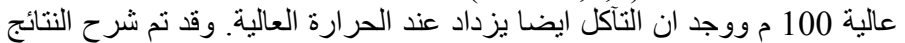

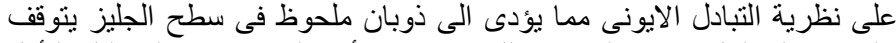

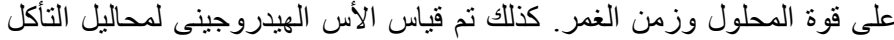

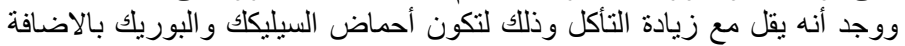

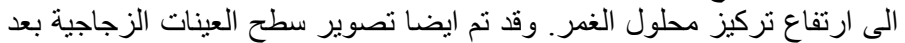

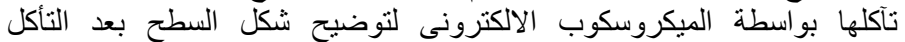

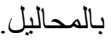

ايضا تم دراسة الصلادة للعينات المحضرة قبل وبعد الغمر فى المحاليل وقد

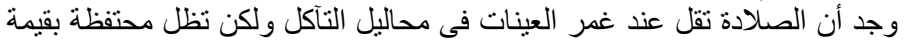

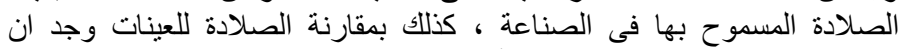

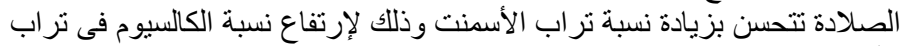

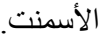

إن من أهم أهداف هذه الدراسة هو المساهمة فى حل المشكلات البيئية الناجمة

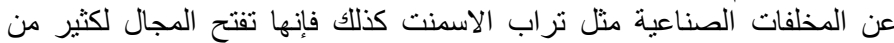

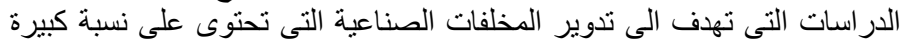

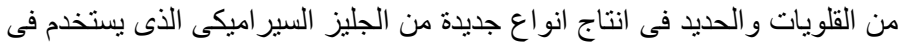

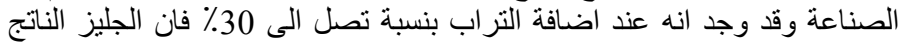
يعطى خصائص جيدة مما يسمح بامكانية تطبيق ذلك عمليا. 